\title{
Efficiency of common water hyacinth (Eichhornia crassipes) in controlling growth of fungal and bacterial clinical strains
}

\author{
Sher Wali ${ }^{*}$, Khushnood ur Rehman ${ }^{1}$, Barkat Ullah ${ }^{1}$, Tabassum Yaseen ${ }^{2}$ \\ and Gulzad Ahmad ${ }^{1}$ \\ 1. Department of Botany, Islamia College, Peshawar-Pakistan \\ 2. Department of Botany, Bacha Khan University, Charsadda-Pakistan \\ *Corresponding author's email: sherwali@icp.edu.pk
}

Citation

Sher Wali, Khushnood ur Rehman, Barkat Ullah, Tabassum Yaseen and Gulzad Ahmad. Efficiency of common water hyacinth (Eichhornia crassipes) in controlling growth of fungal and bacterial clinical strains. Pure and Applied Biology. Vol. 8, Issue 4, pp2178-2186. http://dx.doi.org/10.19045/bspab.2019.80163

\begin{tabular}{llll}
\hline \hline Received: 13/05/2019 & Revised: 15/07/2019 & Accepted: 17/07/2019 & Online First: 25/07/2019 \\
\hline
\end{tabular}

\section{Abstract}

In this paper we have studied the anti-bacterial and anti-fungal potential of Eichhornia crassipes (Mart.) Solms (the common water hyacinth). The main aim was to find a new source against selected bacterial and fungal species was fractionated. Five fractions i.e. n-hexane, aqueous, chloroform, methanolic extracts and ethyl acetate were prepared and tested against four bacterial strains including MRSA (Methicilline resistance staphylococcus aurous), Streptococcus mutansand, Staphylococcus aurous and Serratia marcescense and four fungal strains i.e Alternaria alternate, polyspondylium pallidum, Fusarium oxysporum, Aspergillus flavous. The highest antibacterial activity was displayed by n-hexane fraction (46-48\%) and the lowest activity was shown by crude methanolic extracts $(38-44 \%)$ against all the selected bacterial strains. However in antfungal activities the highest activity was shown by crude methanolic extracts (35-65\%) against the four selected fungal species and lowest activity was displayed by the aqueous fractions. The other fractions have also shown significant activites.

Keywords: Antibacterial; Antifungal; Eichhornia crassipes; Inhibition; Water Hyacinth

\section{Introduction}

At the present time most of the research work is performed to find out the treatment of microbial (fungal and bacterial) diseases from medicinal plants. Such drugs are called traditional drugs with no or very little side effect. Plants contain different chemical compound such as phenols, alkaloids and flavonoids and tannins which play an essential role in the development of medicine and human health. Different extracts obtained from plants such as methanol, ethanol and chloroform have significant effect against antibacterial, antiviral and antitumor diseases [1]. Other natural products of plants are primary and secondary metabolites. The primary metabolites required in sufficient amount for plants and cannot survive without it while the secondary metabolites derived from the primary 
metabolites by different pathways and required in small amount and possess medicinal properties and also have ecological functions [2]. The usage of waste and treatment of high rate algal pond (HRAP) has been researched and developed in 1950s [3]. The comprehensive study of this work was done by [4]. The main aim of this high rate of algal pond (HRAP) is to assimilate nutrient with the help of algae growth which leads to the formation and development of soil. Water hyacinth (Eichhornia crassipes) belongs to monocotyledonous family Pontederiaceae and is a free floating aquatic plant (hydrophyte). Initially it was invaded in aquatic areas of eastern and southern America where it possesses ovate thick and broad leaves and grows up to $1 \mathrm{~m}$ in height [5]. With the help of its complex root system and rapid rate of reproduction it forms dense and interlocking mats which cause ecological and socioeconomic changes $[6,7]$. It contains calcium, magnesium, boron, copper, zinc, aluminum, molybdenum, ferric and potassium which make its growth best over other aquatic species [8, 9]. After dying and decomposition of Eichhornia crassipes the water become eutrophic due to addition of such elements [10, 11]. Although many studies were carried out over the selected plant species such as its role in ecological ecosystem [12, 13]. Antialgal activity was also studies in which different allelochemicals were extracted by fractionation which shown effect over other algal species and also cause inhibition of seeds in many crop plants [14]. The marine and freshwater hydrophytes at one side run the ecosystem and on the other side accumulate different nutrients which are important for human health and other organism [15]. About 25\% medication and $60 \%$ anti-inflammatory and anti-cancer drugs in the markets were prepared in the laboratories from the plant constituents [16]. Initially the antibiotics were very active against different microbes but with the passage of time they loss their activity because of modification in microbes against these antibiotics [17]. Theses microbes cause diseases and about $50 \%$ of the death globally occurred due to these microbial diseases. In this regard the present study was carried out with the aim to find the anti-bacterial and anti-fungal activity of Eichhornia crassipes against four bacteria and four fungal species. The bacterial and fungal species were selected due to their frequent occurrence in local hospitals of Khyber Pakhtunkhwa (KPK) and also showing resistance to different drugs.

\section{Material and methods}

Antibacterial activity

Collection and processing of plant specimen

Different areas of the Khyber Pakhtunkhwa were visited for the collection of E. crassipes plant (Voucher No. H.ICP-1357. The collected plants were washed and dried in shadow followed by oven drying in the oven. The completely drying plants were powdered with the help of grinder. Then the powder stored at cool place before extraction.

\section{Preparation of extraction and fractions}

Cold maceration method was used for the extraction of the active metabolites. One and half of the powder was dipped in two later of ethanol and incubated for 5 days at $40^{\circ} \mathrm{C}$. The material filtered thrice and a clear filtrate was obtained. The filtrate was subjected for evaporation via rotary evaporator at $40^{\circ} \mathrm{c}$. The obtained extract was dried and then dissolved in $100 \mathrm{ml}$ distilled water. The solution was then fractionated by using different organic solvents including ethanol, n-hexane, chloroform, methanol and ethyl acetate by using separating funnel. All the fractions thus obtained were concentrated by rotary evaporator and designate for that solvent fraction. 


\section{Media preparation}

Agar well diffusion method was used during antibacterial activity. A liter of distilled water was used to liquefy $25 \mathrm{~g}$ of Luria Broth; neutral $\mathrm{pH}$ (7.0) was maintained for Miller powder. The media put in autoclave in $250 \mathrm{ml}$ flask. The selected four bacterial stains were introduced into the flask and kept overnight at $150 \mathrm{RPM}$ at $37^{\circ} \mathrm{C}$. After that agar converted into solid form and with the help of sterilized borer five holes were tunneled. The inoculum was introduced into the tunneled. The methods of $[18,19]$ were followed.

\section{Test for bacterial strains}

Among the four selected bacterial strains three were gram positive and one strain was gram negative i.e. MRSA (Methicillin resistance staphylococcus aurous), streptococcus mutans and staphylococcus aurous; while the gram negative bacterium was Serratia marcescens.

\section{Measurement of zones of inhibition}

Dimethyl sulfoxide $20 \mathrm{mg} / \mathrm{ml}$ was used as a negative control in which the extracts were dissolved. While Cefotaxime (standard antibiotics) was used as a positive control. The plant fractions about $75 \mu \mathrm{l}$ were introduced into the wells of petri dish and that petri dishes were placed in the incubator for 24 hours at $37^{\circ} \mathrm{c}$ (Figure 1). When the incubation period was completed then the diameter of each transparent zone was measured. The experiment was repeated again and again to calculate the standard data.

\section{Test for fungal strains}

During antifungal activity the four fungal strains were selected i.e Fusarium oxysporum, Aspergillus flavous, polyspondylium pallidum, and Alternaria alternate.

\section{Results and discussion}

The current research work was carried out to evaluate the anti-fungal and anti-bacterial potential of the Eichhornia crassipes (Mart.) Solms (the common water hyacinth). The results revealed that this plant is an effective source for the inhibition of the growth of tested species of both bacteria and fungi. The plant can be investigated for active metabolites to evolve the anti-bacterial and anti-fungal drugs through biochemical and biophysical essays.

Antibacterial activities of Eichhornia crassipes

In the current research work five fractions of Eichhornia crassipes extracts were used to know their potential use against the selected bacterial strains that are Staphylococcus aureus, Streptococcus mutans and Methicillin-resistant Staphylococcus aureus (MRSA) and Serratia marcescens. Results of the anti-fungal activity as shown in (Table 1) showed that all the fractions were active against the tested bacterial strains. The growth of Staphylococcus aureus, Streptococcus mutans, Serratia marcescens and Methicillin-resistant Staphylococcus aureus (MRSA) was inhibited by the crude methanolic extract with $10.0 \mathrm{~mm}, 12.0 \mathrm{~mm}$, $09.0 \mathrm{~mm}$ and $11.0 \mathrm{~mm}$ zones of inhibition respectively. The $n$. hexane extracted fractions inhibited the growth of Staphylococcus aureus, Streptococcus mutans, Serratia marcescens and Methicillin-resistant Staphylococcus aureus (MRSA) with $12.0 \mathrm{~mm}, 13.0 \mathrm{~mm}, 14.0 \mathrm{~mm}$ and $10.0 \mathrm{~mm}$ zones of inhibition respectively. The chloroform fractions were produced $11.0 \mathrm{~mm}, 14.0 \mathrm{~mm}, 07.0 \mathrm{~mm}$ and $14.0 \mathrm{~mm}$ zones of inhibition against Staphylococcus aureus, Streptococcus mutans, Serratia marcescens and Methicillin-resistant Staphylococcus aureus (MRSA) respectively. The ethyl acetate fraction was most active against Streptococcus mutans (ZOI $=10.0 \mathrm{~mm})$ followed by Methicillinresistant Staphylococcus aureus (ZOI=09.0mm), Staphylococcus aureus $(\mathrm{ZOI}=08.0 \mathrm{~mm})$ and Serratia marcescens $(\mathrm{ZOI}=08.0 \mathrm{~mm})$. The aqueous extracted fraction inhibited the growth of tested bactrail strains in the order of Methicillin- 
resistant Staphylococcus aureus (ZOI $=08.0 \mathrm{~mm}), \quad$ Staphylococcus aureus $(\mathrm{ZOI}=05.0 \mathrm{~mm}), \quad$ Serratia marcescens $(\mathrm{ZOI}=05.0 \mathrm{~mm})$ and Streptococcus mutans (ZOI=04.0mm) respectively (Figure 2). According to [20] in the previous century most of the faculties in the medicine sector switched their concern from natural to synthetic drugs. But for the last few decades this trend is shifting in the reverse direction [21]. In a survey $25 \%$ of the drug prescriptions in 35 countries are plants derived in non-modified or little modified $[22,23]$.

\section{Antifungal activities of Eichhornia crassipes}

Results of the anti-fungal activity as shown in (Table 2) revealed that the n-hexane extracted sample inhibited the growth of Fusarium oxysporum completely. Chloroform and Ethyl acetate inhibited the growth of Polysphondylium pallidum. While the aqueous extract showed significant activity against Aspergillus flavus and Alternaria alternate. Crude methanolic extract showed good results against Polysphondylium pallidum. Trend in results revealed that Fusarium oxysporum is comparatively more sensitive to the n-hexane extracts, Polysphondylium pallidum to chloroform and Ethyl acetate extracts while Aspergillus flavus and Alternaria alternate to the aqueous extracts of plants (Figure 3). The usage of medicinal plants as anti-fungals is quite old practice performed by human beings. These result in the production of important compounds that are used to develop drugs against fungal pathogens. One of the positive aspects of these drugs is that these drugs have very little adverse/side effects on the human health [24]. The demand for the development anti-fungal drugs has enormously increased. It is established that among others fungal pathogens are causing serious losses in the quantity, quality, shelf life and mortality of the crop plants [25]. In regard to humans, fungi as the cause of diseases offer a new aspect of human pathology [26]. In this regard medicinal plants are proved to be the sources for the discovery of new drugs [27]. In the developing countries, which face the problems of the quantity and quality of modern drugs, medicinal plants derived compounds have recently gained much importance and their old traditional uses are valued more nowadays [28]. The current study revealed that antifungal activity of the wild plants proved to be more significant and can be a very suitable substitute of the modern medicines. Similar findings have been reported by [29] for the fungus Alternaria alternate. Similarly [30] revealed that the crude methanolic extract of the medicinal plants showed maximum antifungal properties which is in agreement with our work. Similar results with other medicinal plants were reported by [31]. 
Pure Appl. Biol., 8(4): 2178-2186, December, 2019

http://dx.doi.org/10.19045/bspab.2019.80163
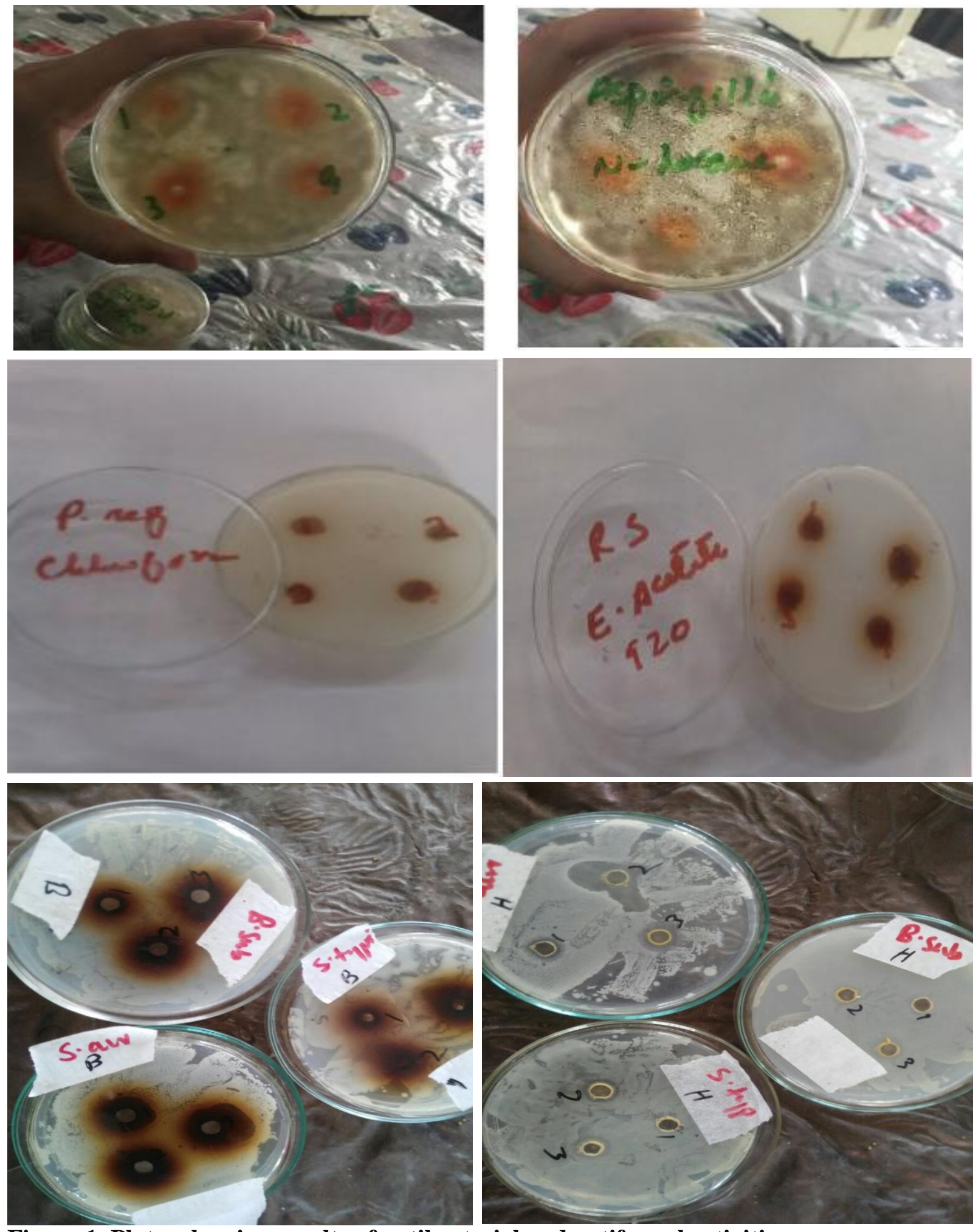

Figure 1. Plates showing results of antibacterial and antifungal activities 


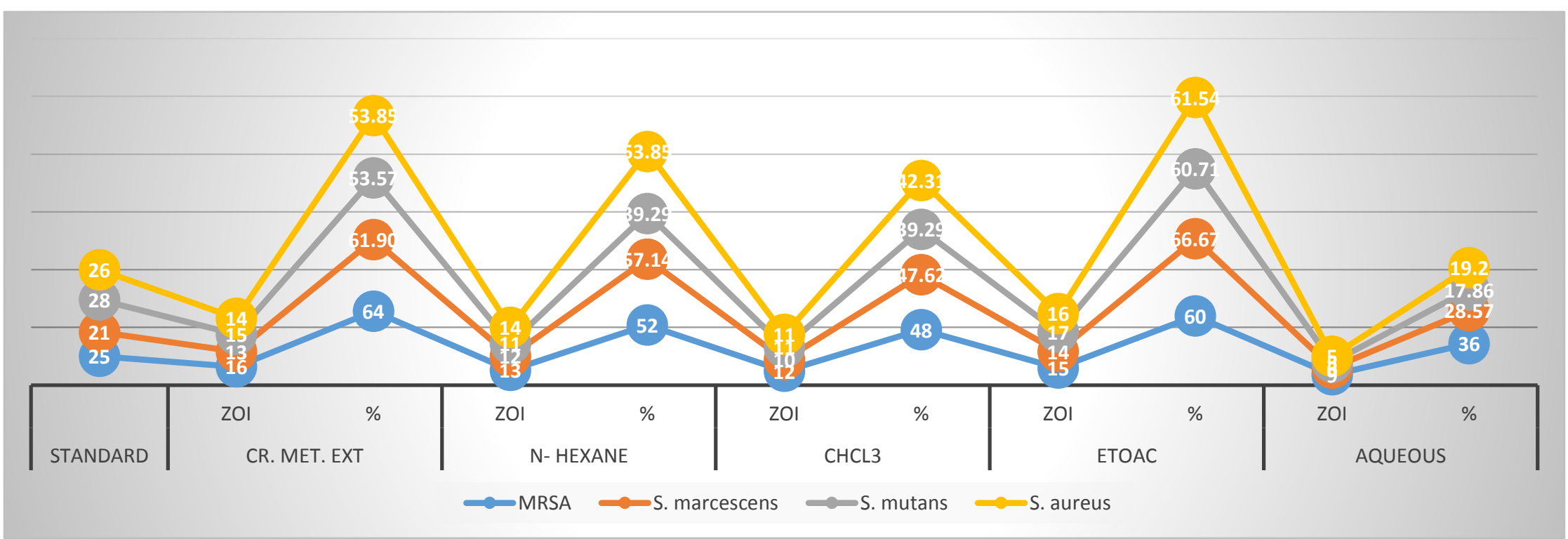

Figure 2. Antibacterial efficacy of Eichhornia crassipes (Mart.) Solms in different solvents

Table 1. Antibacterial activities of Eichhornia crassipes (Mart.) Solms against selected strains

\begin{tabular}{|c|c|c|c|c|c|c|c|c|c|c|c|}
\hline \multirow{2}{*}{$\begin{array}{c}\text { Bacterial } \\
\text { Species }\end{array}$} & \multirow{2}{*}{ Standard } & \multicolumn{2}{|c|}{ Cr. Met. Ext } & \multicolumn{2}{|c|}{$n$-hexane } & \multicolumn{2}{|c|}{$\mathrm{CHCl}_{3}$} & \multicolumn{2}{|c|}{ EtOAc } & \multicolumn{2}{|c|}{ Aqueous } \\
\hline & & ZOI & $\%$ & ZOI & $\%$ & ZOI & $\%$ & $\mathrm{ZOI}$ & $\%$ & ZOI & $\%$ \\
\hline MRSA & $25.0 \pm 0.67$ & $16 \pm 0.56$ & 44.0 & $13 \pm 0.90$ & 48 & $12.0 \pm 0.57$ & 40 & $15.0 \pm 0.87$ & 36 & $09.0 \pm 0.23$ & 32 \\
\hline S. marcescens & $21.0 \pm 0.87$ & $13.0 \pm 0.56$ & 42.8 & $12 \pm 0.88$ & 47.6 & $10 \pm 0.45$ & 33.3 & $14.0 \pm 0.44$ & 38.1 & $06.0 \pm 0.22$ & 23.8 \\
\hline S. mutans & $28.0 \pm 0.60$ & $15.0 \pm 0.67$ & 42.8 & $11 \pm 0.66$ & 46.4 & $11.0 \pm 0.56$ & 50 & $17.0 \pm 0.34$ & 35.7 & $05.0 \pm 0.34$ & 14.2 \\
\hline S. aureus & $26.0 \pm 0.56$ & $14.0 \pm 0.87$ & 38.4 & $14 \pm 0.93$ & 46.1 & $11.0 \pm 0.21$ & 42.3 & $16.0 \pm 0.33$ & 30.7 & $05.0 \pm 0.50$ & 19.2 \\
\hline
\end{tabular}




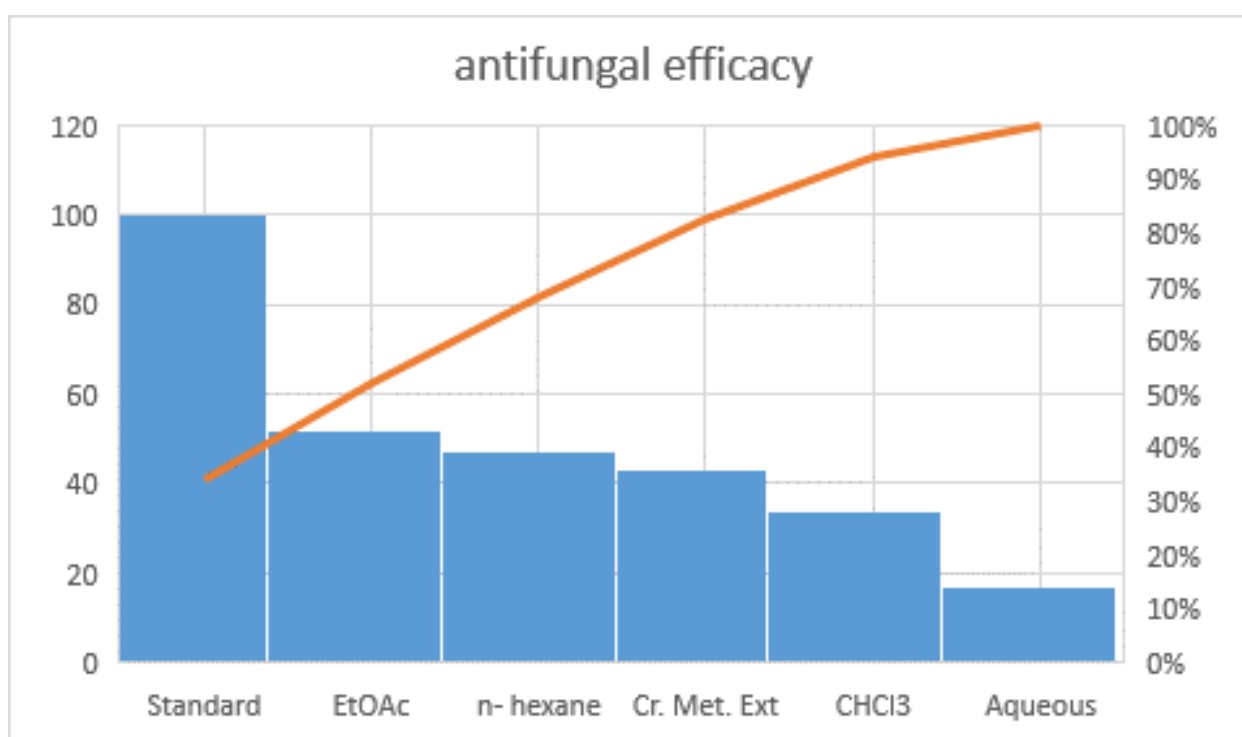

Figure 3. Antifungal efficacy of Eichhornia crassipes (Mart.) Solms in different solvents

Table 2. Antifungal activities of Eichhornia crassipes (Mart.) Solms against selected strains

\begin{tabular}{|c|c|c|c|c|c|c|c|c|c|c|c|}
\hline \multirow{2}{*}{$\begin{array}{l}\text { Fungal } \\
\text { Species }\end{array}$} & \multirow{2}{*}{ Standard } & \multicolumn{2}{|c|}{ Cr. Met. Ext } & \multicolumn{2}{|c|}{$n$ - hexane } & \multicolumn{2}{|c|}{$\mathrm{CHCl}_{3}$} & \multicolumn{2}{|c|}{ EtOAc } & \multicolumn{2}{|c|}{ Aqueous } \\
\hline & & ZOI & $\%$ & ZOI & $\%$ & ZOI & $\%$ & ZOI & $\%$ & ZOI & $\%$ \\
\hline A.flavus & $100.0 \pm 0.00$ & $43 \pm 0.52$ & 43 & $47.0 \pm 0.78$ & 47 & $34.0 \pm 0.53$ & 34 & $52.0 \pm 0.44$ & 52 & $17.0 \pm 0.11$ & 17 \\
\hline A. alternate & $100.0 \pm 0.00$ & $68.0 \pm 0.53$ & 68 & $39.0 \pm 0.88$ & 39 & $45.0 \pm 0.61$ & 45 & $48.0 \pm 0.14$ & 48 & $15.0 \pm 0.12$ & 15 \\
\hline F. oxysporum & $100.0 \pm 0.00$ & $59.0 \pm 0.21$ & 59 & $21.0 \pm 0.00$ & 21 & $37.0 \pm 0.45$ & 37 & $59.0 \pm 0.19$ & 59 & $23.0 \pm 0.34$ & 23 \\
\hline P. pallidum & $100.0 \pm 0.00$ & $39.0 \pm 0.14$ & 39 & $32.0 \pm 0.67$ & 32 & $20.0 \pm 0.34$ & 20 & $36.0 \pm 0.23$ & 36 & $25.0 \pm 0.23$ & 25 \\
\hline
\end{tabular}




\section{Conclusion}

It is evident from the results of anti-bacterial and anti-fungal activities that the selected plant i.e. Eichhornia crassipes possessed very significant properties. The crude methanolic and ethanolic extracts were comparatively more active which clarified that polar solvents dissolved more properly in the polar solvents.

\section{Authors' contributions}

Conceived and designed the experiments: $S$ Wali, K Rehman \& B Ullah, Performed the experiments: $\mathrm{K}$ Rehman, $\mathrm{T}$ Yaseen \& $\mathrm{G}$ Ahmad, Analyzed the data: S Wali, K Rehman \& G Ahmad, Contributed materials/ analysis/ tools: K Rehman, S Wali \& G Ahmad, Wrote the paper: S Wali, K Rehman, B Ullah, T Yaseen \& G Ahmad.

\section{References}

1. Shanab SM, Shalaby EA, Lightfoot DA \& El-Shemy HA (2010) Allelopathic effects of water hyacinth (Eichhornia crassipes). PloS One 5, e13200.

2. Pagare S, Manila B, Tripathi N \& Bansal YK (2015). Secondary metabolites of plants and their role: Overview. Curr Trends in Biotechnol and Pharmacy 9: 293-304.

3. Oswald WJ, Gotaas HB, Golueke CG, Kellen WR, Gloyna EF \& Hermannn ER (1957). Algae in Waste Treatment [with Discussion]. Sewage and Industrial Wastes 29: 437-457.

4. Fallowfield HJ \& Garrett MK (1985b) Treatment of wastes by algal culture. In Brown CM, White WR (eds) Microbial aspects of water. Society for Applied Bacteriology Symposium No. 14, Academic Press, London.

5. Mitchell DS (1985) Surface-floating aquatic macrophytes. In: The Ecology and Management of African Wetland Vegetation (Eds P. Denny), pp 109-124.

6. Center T.D. (ed.) (1994) Biological Control of Weeds: Hyacinth and Water Lettuce. Intercept, Andover.

7. Villamagna AM \& Murphy BR (2010) Ecological and socio-economic impacts of invasive water hyacinth (Eichhornia crassipes): a review. Freshwater Biol 55(2): 282-298

8. Verma S, Vashishth E, Singh R, Kumari A, Meena A, Pant, P, Bhuyan G \& Padhi M (2013). A review on parts of Albizia lebbeck (L.) Benth. used as ayurvedic drugs. Res J Pharm Technol 6: 13.

9. Dandelot S, Robles C, Pech N, Cazaubon A \& Verlaque R (2008). Allelopathic potential of two invasive alien Ludwigia spp. Aquatic Bot 88: 311-316.

10. Gao L \& Li B (2004). The study of a specious invasive plant, water hyacinth (Eichhornia crassipes): Achievements and challenges. Acta Phytoecologica Sinica 28: 735-752.

11. Shanab SM \& Shalaby EA (2012). Biological activities and anticorrosion efficiency of water hyacinth (Eichhornia crassipes). J of Med Plants Res 6: 39503962.

12. Jayanthi $P$, Lalitha $P$, Sujitha $R$ \& Thamaraiselvi A (2013). Antiinflammatory activity of the various solvent extracts of Eichhornia crassipes (Mart.) Solms. Inter J Pharm Tech Res, 5: 641-4.

13. Gutiérrez-Morales A, VelázquezOrdoñez V, Khusro A, Salem AZ, Estrada-Zúñiga ME, Salem MZ, Valladares-Carranza B \& BurrolaAguilar C (2017). Anti-staphylococcal properties of Eichhornia crassipes, Pistacia vera, and Ziziphus amole leaf extracts: Isolates from cattle and rabbits. Microbial Pathogenesis 113: 181-189.

14. Lewis MA (1995). Use of freshwater plants for phytotoxicity testing: a review. Environ Pollu 87: 319-336.

15. Hu H \& Hong Y (2008). Algal-bloom control by allelopathy of aquatic macrophytes - a review. Frontiers of Environ Sci \& Eng in China 2: 421-438.

16. Pandey D (1996). Phytotoxicity of sesquiterpene lactone parthenin on 
aquatic weeds. J of Chem Ecol 22: 151160.

17. Das S, Goswami S \& Talukdar AD (2016). Physiological responses of water hyacinth, Eichhornia crassipes (Mart.) Solms, to cadmium and its phytoremediation potential. Turk $J$ of Biol 40: 84-94.

18. Perez G, Avila A \& Martinez C (1990). Antimicrobial activity of some American algae. $J$ of Ethnopharmacol 29: 111-116.

19. Samie A, Tambani T, Harshfield E, Green E, Ramalivhana J \& Bessong P (2010). Antifungal activities of selected Venda medicinal plants against Candida albicans, Candida krusei and Cryptococcus neoformans isolated from South African AIDS patients. African $J$ of Biotechnol 9.

20. Lu X, Gao Y, Luo J, Yan S, Rengel Z \& Zhang $\mathrm{Z}$ (2014). Interaction of veterinary antibiotic tetracyclines and copper on their fates in water and water hyacinth (Eichhornia crassipes). J of Hazardous Materials 280: 389-398.

21. Cardoso SF, Lopes LM \& Nascimento IR (2014). Eichhornia crassipes: an advantageous source of shikimic acid. Revista Brasileira de Farmacognosia 24: 439-442.

22. Joshi M \& Kaur S (2013). In vitro evaluation of antimicrobial activity and phytochemical analysis of Calotropis procera, Eichhornia crassipes and Datura innoxia leaves. Asian J Pharm Clin Res 6: 25-28.

23. Lata N \& Dubey V (2010). Quantification and identification of alkaloids of Eichhornia crassipes: the world's worst aquatic plant. J Phar Res 3: 1229-1231.
24. Aboul-Enein AM, Al-Abd AM, Shalaby E, Abul-Ela F, Nasr-Allah AA, Mahmoud AM \& El-Shemy HA (2011). Eichhornia crassipes (Mart) solms: from water parasite to potential medicinal remedy. Plant Signaling \& Behavior 6: 834-836.

25. Baral B \& Vaidya GS (2011). Biological and chemical assessment of water hyacinth (Eichhornia crassipes (mart.) Solms.) of Phewa Lake, Nepal. Scientific World 9: 57-62.

26. Tulika T \& Mala A (2015). Pharmaceutical potential of aquatic plant Pistia stratiotes (L.) and Eichhornia crassipes. J of Plant Sci 3: 10-18.

27. Madsen GC \& Pates AL (1952). Occurrence of antimicrobial substances in chlorophyllose plants growing in Florida. Botanical Gazette 113: 293-300.

28. Chang CC, Tan HC \& Cheng W (2013). Effects of dietary administration of water hyacinth (Eichhornia crassipes) extracts on the immune responses and disease resistance of giant freshwater prawn, Macrobrachium rosenbergii. Fish \& Shellfish Immunol 35: 92-100.

29. Isebe TI (2016). Phytochemical composition and antibacterial activity of Eichhornia Crassipes in Lake Victoria, Kisumu. Inter J of Scientific and Technol Research, 5: 45-52.

30. Lalitha P, Sripathi SK \& Jayanthi P (2012). Acute toxicity study of extracts of Eichhornia Crassipes (Mart.) Solms. Asian J of Pharma and Clin Res 5: 5961.

31. Singhal PK, Varghese L \& Talegaonkar L (1993). Abiotic and microbial decomposition of pre-and post-bloom leaves of water hyacinth (Eichhornia crassipes (Mart.) Solms). Hydrobiol 259: 115-119. 